\title{
Recent land cover changes on the Tibetan Plateau: a review
}

\author{
Xuefeng Cui • Hans-F. Graf
}

Received: 22 February 2008 / Accepted: 30 December 2008 / Published online: 24 February 2009

(C) The Author(s) 2009. This article is published with open access at Springerlink.com

\begin{abstract}
This paper reviews the land cover changes on the Tibetan Plateau during the last 50 years partly caused by natural climate change and, more importantly, influenced by human activities. Recent warming trends on the plateau directly influence the permafrost and snow melting and will impact on the local ecosystem greatly. Human activities increased rapidly on the plateau during the last half century and have significant impacts on land use. Significant land cover changes on the Tibetan Plateau include permafrost and grassland degradation, urbanization, deforestation and desertification. These changes not only impact on local climate and environment, but also have important hydrological implications for the rivers which originate from the plateau. The most noticeable disasters include the flooding at the upper reaches of Yangtze River and droughts along the middle and lower reaches of Yellow River. Future possible land cover changes under future global climate warming are important but hard to assess due to the deficits of global climate model in this topographically complex area. Integrated investigation of climate and ecosystems, including human-beings, are highly recommended for future studies.
\end{abstract}

Submitted to Climatic Change on 6th June 2007 for YSC Special Issue.

\footnotetext{
X. Cui $(\varangle)$

Department of Geography, University of Liverpool,

Roxby Building, Liverpool L69 7ZT, UK

e-mail: x.cui@liverpool.ac.uk

X. Cui

Institute of Atmospheric Physics,

Chinese Academy of Sciences, Beijing, China

H.-F. Graf

Centre for Atmospheric Science,

University of Cambridge, Cambridge, UK
} 


\section{Introduction}

Mountainous and high-elevated regions, such as the Tibetan Plateau (TP), are very vulnerable to climate change (e.g. Beniston 2003) and seem to have warmed more, and perhaps sooner than the rest of the globe (Beniston et al. 1996). Climate change influences vegetation distribution and land cover changes (LCC) influence climate as well (e.g. Charney 1975) through biogeophysical effects (Brovkin et al. 2004) such as changing surface roughness, evapotranspiration, and albedo, and via biogeochemical feedbacks (Stich et al. 2005), like $\mathrm{CO}_{2}$ emissions into the atmosphere (Houghton and Hackler 2003). Between one third and one half of the Earth's land surface has been directly transformed by human activities (Vitousek et al. 1997). The ecosystem on the TP, as one of the cleanest and unpolluted areas in the world, is extremely fragile, and its ability to resist distortion and to regenerate is weak. Once the ecosystem is damaged, it is hard to restore it for a long period of time. This paper is aimed to review the recent land cover changes on the TP during the last 50 years and to stimulate further investigation and possible actions by discussing the possible causes for such changes. Section 2 will briefly introduce the climate background of the $\mathrm{TP}$ and Section 3 discusses the recent land cover changes. In Section 4, the future possible scenarios are discussed and a summary and conclusion is given in Section 5.

\section{Climate background of the Tibetan Plateau}

\subsection{Importance of the Tibetan Plateau}

The TP is a huge mountainous area of the Eurasian continent, with millions of square $\mathrm{km}$ area and an average altitude of 4,000 $\mathrm{m}$. Figure 1 shows the geographic location and orographic characteristics of the TP. It is mostly located in China covering the

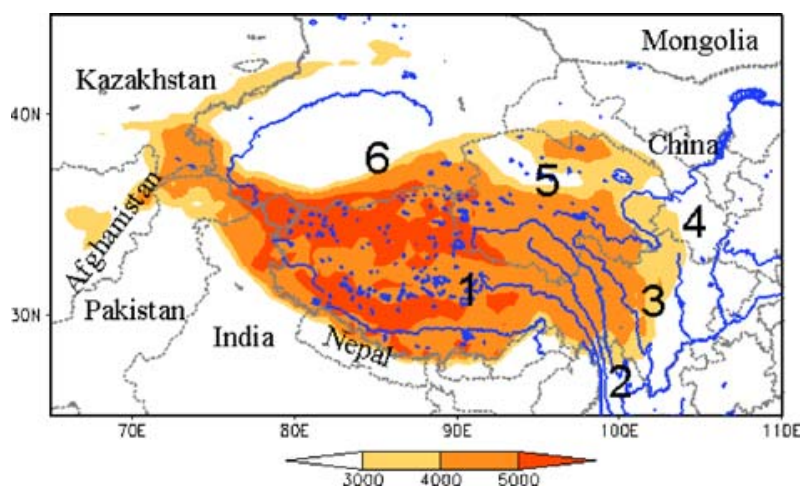

Fig. 1 Geographic location of the Tibetan Plateau is shown as the shaded region where topography is higher than 3,000 m. Grey dashed contour lines show the boundaries between countries or the provinces in China. The Tibetan Plateau in China covers 1 the Tibet Autonomous Region and parts of 2 Yunnan province, 3 Sichuan province, 4 Gansu province, 5 Qinghai province, and 6 Xinjiang province. Blue contour lines or circles represent the rivers or lakes in China 
Tibet Autonomous Region (normally referred to as Tibet, hereafter referred to as TAR in this paper to distinguish with TP), Yunnan, Sichuan, Qinghai, Gansu, and Xinjiang provinces. Some parts are located in Tajikistan, Pakistan, India, and Nepal. Because of its height and size, it plays an important role in determining the formation and variation of regional weather and climate in East and South Asia, as well as the Northern Hemisphere atmospheric circulation in general (e.g. Manabe and Terpsta 1974; Manabe and Broccoli 1990). Following Ye and Gao (1979) and other studies, the effects of the TP on the atmosphere can be divided into three major categories as follows:

(A) Dynamic Effect: The TP exerts a dynamic orographic blocking effect to zonal and meridional air motions by its presence and shape, resulting in strong horizontal and vertical perturbations of atmospheric flows (e.g. Ye and Gao 1979).

(B) Thermodynamic Effect: In summer, the TP acts as an elevated heat source and moisture sink affecting the atmospheric circulation (e.g. Hsu and Liu 2003; Sato and Kimura 2007).

(C) Surface Indirect Effect: The complex terrain and variable boundary conditions of the TP create a unique weather and climatic system in the middle troposphere above 4,000 m (e.g. Shimizu et al. 2001). The active local atmospheric systems (like meso-scale convective systems, frontal systems, and "Tibetan vortices") at the TP and along the slope greatly modify the large-scale circulation (e.g., Ye and Wu 1998).

Land cover on the TP varies greatly including forest, grassland, shrubland, glaciers to bare land and its changes will not only exert changes of local climate but also influence remote areas through the aforementioned effects, especially the latter two. It is also worth mentioning that the $\mathrm{TP}$ is also the source region for several major rivers in southeastern and eastern Asia, including the Yellow River, Yangtze River, Mekong River, and Salween River (shown in Fig. 1). Although precipitation on the TP is not large (Ueno et al. 2001), the runoff is considerable due to steep topography, melting of glacier/ice mass, and low evaporation, which is limited by low surface temperatures (Kondo and $\mathrm{Xu}$ 1997; Xu and Haginoya 2001). Land surface changes (vegetation, ice/snow, permafrost) in the source areas of the rivers could influence the river systems originating from here, leading to disruptions of the existing socioeconomic structures of populations living on the TP and those living downstream (Beniston et al. 1996).

\subsection{Climate of the Tibetan Plateau}

Since ecological and biogeochemical processes are highly sensitive to climatic variability and disturbances (Du et al. 2004) it is essential to study the climate background and recent changes first. As the TP is characterized by very complex terrain and weather stations are biased to the eastern, lower elevation and populated areas, existing observational data are not ideal for assessing long-term trends on the TP (Frauenfeld et al. 2005). Caution needs to be taken when assessing regional characteristics from these limited station observations. 


\subsubsection{Surface temperature}

The surface temperature on the TP is relatively low with very strong gradients along the periphery due to its high altitude, which made it a very fragile environment for vegetation growth. Temperature increases from north-west to south-east while the altitude decreases. During winter the TP is characterized by monthly averaged temperatures around $-25^{\circ} \mathrm{C}$ in the west and $-15^{\circ} \mathrm{C}$ in the east. In summer, the entire TP's averaged temperature rises above $0^{\circ} \mathrm{C}$. The east warms up to $5-10^{\circ} \mathrm{C}$, and the high elevations of the west warm up to $0-5^{\circ} \mathrm{C}$. In addition to the seasonal variations, near surface air temperatures over the TP also have strong diurnal variations because of the strong incoming solar radiation during daytime. The diurnal change of the surface soil temperature can be up to $50^{\circ} \mathrm{C}$ in spring, while it reduces to about $20^{\circ} \mathrm{C}$ in the summer monsoon season as the surface becomes wet due to frequent precipitation (Tanaka et al. 2003).

Analyses of temperature series of 97 stations showed that most of the TP has experienced statistically significant warming since the mid-1950s, especially in winter. The linear rate of temperature increase over the TP during the period of 19551996 was about $0.16^{\circ} \mathrm{C} /$ decade for the annual mean and $0.32^{\circ} \mathrm{C} /$ decade for the winter mean, exceeding those for the Northern Hemisphere and the same latitudinal zone in the same period (Liu and Chen 2000). Frauenfeld et al. (2005) confirmed such warming trends on the TP during the period of 1957-2000 based on the analysis of 161 station records. Station records show statistically significant decreasing of the number of frost days and ice days and a longer growing season (You et al. 2008). The temperature variation on the TP has different sub-regional regimes (Yin et al. 2000). Temperature is found cooling in the western Himalayas in pre-monsoon season during the later part of the 20th century from observational records and from reconstructions using tree rings (Yadav et al. 2004). Surface temperature changes on the TP will greatly influence the dates of thaw processes and permafrost conditions and therefore impact vegetation growth and hydrology.

\subsubsection{Precipitation}

The amount of precipitation on the TP is small and extremely variable in time and space (Ueno et al. 2001), resulting in a large spatial variability of soil water content, as well as of sensible and latent heat fluxes from the surface (Xu and Haginoya 2001). Summer precipitation accounts for more than $60 \%$ of the total annual precipitation. Therefore, its variability is important for many ecological processes as well as for human activities in this region. The normalized difference vegetation index (NVDI) is found highly correlated with precipitation variations in the grassland with medium vegetation cover (Ding et al. 2007), Precipitation gradually decreases from southeast to northwest, from approximately $700 \mathrm{~mm}$ to less than $50 \mathrm{~mm}$ annually (Liu and Yin 2002). Correspondingly, the vegetation cover also varies from forest in the southeast to desert in the northwest.

Lin and Zhao (1996) pointed out that the precipitation changes on the TP are highly variable from region to region. The southeast of the TP received more precipitation during the last 40 years, while the northeast was getting drier as shown by station records (Niu et al. 2004). Tree ring records show a positive trend of late 
summer rainfall in the southeast TP for the period of 1961-1990 (Braeuning and Mantwill 2004) and an increase of spring precipitation since the 1970s over the western Himalayan region (Singh and Yadav 2005). The level of Qinghai Lake, the largest lake on the TP, has fallen dramatically and it shrunk in area since the beginning of the 20th century, suggested mainly to be due to the decrease of precipitation in the catchment (Qin and Huang 1998). However, a recent study reveals that no significant trends can be found in the precipitation frequency or intensity from station observations (You et al. 2008).

\subsubsection{Data issues}

By making optimal use of the few available observations, there is great hope that meteorological analyses and forecasts can provide a more complete and reliable picture of the climate in this region. Temperature and precipitation in reanalysis data are highly dependent on model performance (Bengtsson et al. 2004). Unfortunately, the TP is not the region which benefits from large development and validation efforts. Frauenfeld et al. (2005) found that, other than in the surface observations, there are no significant trends on the TP in its $2 \mathrm{~m}$ temperature from the European Centre for Medium-Range Weather Forecasts (ECMWF) Reanalysis (ERA40; Simmons and Gibson 2000) during the last 40 years. Apart from the biases of the data on the TP, the extensive local and regional land use changes could be a potential explanation for the difference between reanalysis data and station trends (Kalnay and Cai 2003) as these land use changes were not incorporated in the reanalysis model system. Hence, the increasing differences between station observations and reanalysis may hint towards the effects of land use change.

Scientific campaigns have helped improving our understanding of landatmosphere interactions on the TP and the obtained observational data are important to validate global datasets, e.g. satellite data (Ma et al. 2006) or reanalysis data, which have not implemented any observations from the TP to date (Frauenfeld et al. 2005). So far, there are four major campaigns that have been performed on the TP:

- QXPMEX: The first Qinghai-Xizang (Tibetan) Plateau Meteorological Experiment from May to August in 1979;

- TIPEX: the second Tibetan Plateau Experiment of Atmospheric Science during May to August in 1998;

- GAME-Tibet: Launched in 1996, it is an international land-atmosphere interaction field experiment implemented on the TP both at the plateau scale and mesoscale under the framework of the Global Energy and Water-cycle Experiment (GEWEX) Asian Monsoon Experiment (GAME) within the World Climate Research Program (WCRP). As one of nine Continental Scales Experiments (CSEs), GAME-Tibet had a pre-phase observation period (POP) in 1997 and an intensive observation period (IOP) in 1998 (Ma et al. 2003). More information can be found at http://monsoon.t.u-tokyo.ac.jp/Tibet/;

- CAMP/Tibet: Coordinated Enhanced Observation Period (CEOP) AsiaAustralia Monsoon Project (CAMP) on the Tibetan Plateau during 2001-2005 (Ma et al. 2006). 


\section{Land cover changes on the Tibetan Plateau}

Vegetation distribution on the plateau has been shown to be very sensitive and vulnerable to environmental change due to the high altitude of the plateau, where growth and distribution of plants depend heavily on the local climate conditions (Zhang et al. 1996b). The development of the vegetation and environment went through several transitions responding to climate changes (Tang et al. 1998). This section will review the land cover changes during the last 50 years only. It is necessary, however, to state that the data are inhomogeneous and there is no way to clearly assess changes without additional information that is currently not available.

The TP is a unique natural landscape, with broad areas of intricate physiognomic types. Thus, remote sensing data sets are very powerful tools to evaluate land cover changes for this region (Suh and Lee 2004; Xu et al. 2008). Figure 2 shows the land cover maps for the years 1950 and 2000. Both years were assessed with different methods and hence the differences may result either from methodological reasons or may reflect real changes. Figure 2 a shows the dominant land cover types on the $\mathrm{TP}$ in the year 1950 based on data from the International Satellite Land Surface Climatology Project (ISLSLP) initiative II data collection (Klein Goldewijk 2001). It shows a clear horizontal and vertical variation of vegetation patterns caused by temperature and humidity differences (Song et al. 2004). There are forests located at the southeast part and grassland/steppe on the northern and western boundaries. Tundra is the major land cover type in central TP. Figure $2 b$ shows the dominant land cover types on the TP in the year 2000 with data obtained from the Global Land Cover 2000 database (GLC2000 2003). In the year 2000, the vegetation types are largely different from the earlier assessment. Types vary gradually from cropland in the southeast region to temperate shrubland/meadow in the middle region to temperate desert, alpine desert, ice/polar desert in the northwest region. To summarize, tundra was generally replaced by shrubland in the central Plateau. Warm and conifer forests at the southeastern TP almost disappeared and changed mainly into cropland. Bare land shows up at the western border of the Plateau replacing the original grassland/Steppe found there in 1950. However, one has to bear in mind that the two datasets are using different schemes of vegetation types of classification, although we tried to merge similar classes into one. We are not aware of any systematic comparison of the two data sets so far that might shed light on which parts of the changes are due to the data compilation and which part is real. Apart from the uncertainties coming from different datasets, there are high uncertainties on the TP in the land surface data itself which is derived from satellite images (Ma et al. 2006). Only comprehensive scientific surveys on the TP could help learning more about the natural eco-environment in a more systematic and profound manner. Although such studies are limited in number, time and space covered, they have helped disclosing some land cover changes on the TP. In the following section, we review such findings from the literature.

\subsection{Permafrost degradation}

The highest and most extensive high-altitude permafrost on Earth is located on the Qinghai-Tibet Plateau (Liu and Chen 2000), which is about $1.5 \times 10^{6} \mathrm{~km}^{2}$ and plays a very important role in determining vegetation distribution and dynamics as well 
as in indicating changes and fluctuations of climate (Yang et al. 2004). The lower altitude limit of permafrost has risen by $40-80 \mathrm{~m}$ on the TP (Wang et al. 2000) with the northern boundary of permafrost having retreated $0.5-1.0 \mathrm{~km}$ towards the south and the southern boundary 1-2 km towards the north under the effect of the climate change (Tong and Wu 1996). Regional lowering of groundwater tables triggered by degrading permafrost has become one of the major factors responsible for the deteriorating environment, as evidenced by dropping lake water levels, shrinking wetlands, and degenerating grasslands (Cheng and Wu 2007). The degradation of permafrost can directly lead to significant degradation of alpine cold meadow and

Fig. 2 Land cover

distributions on the Tibetan Plateau in a 1950 and b 2000. Elevation levels of 3,000, 4,000, and 5,000 $\mathrm{m}$ are shown for reference. Data sources are given in the text a) 1950

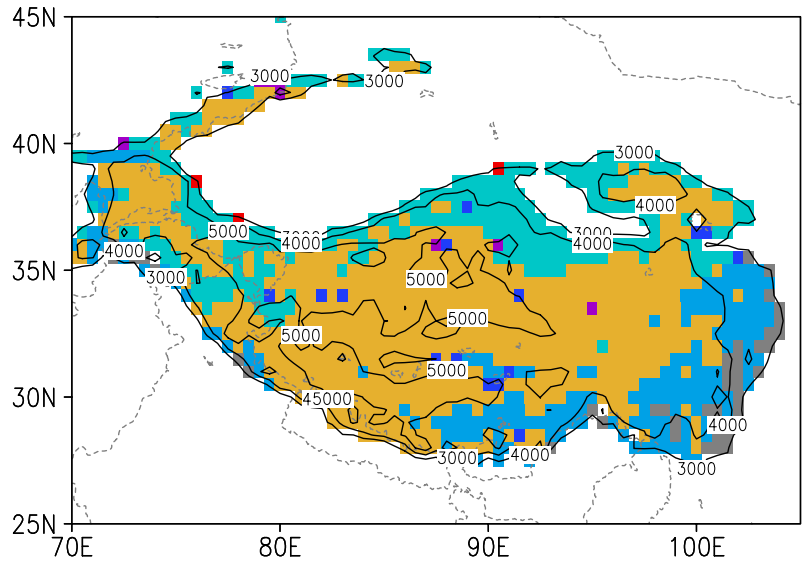

b) 2000

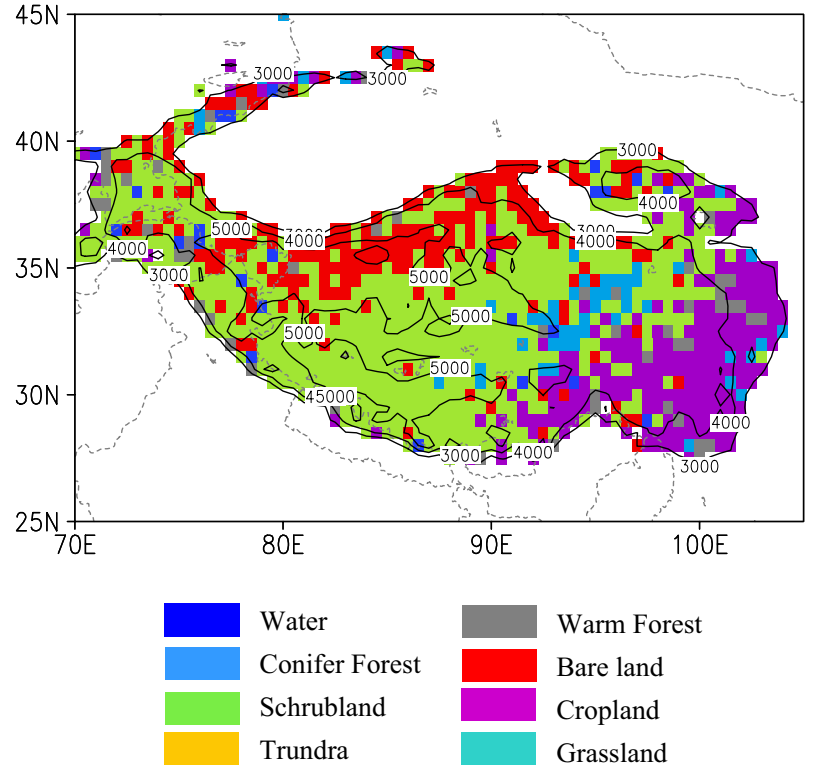


alpine cold swamp meadow, but has less influence on alpine cold steppe ecosystems (Wang et al. 2006). Permafrost degradation will likely cause a drier ground surface (Cheng and Wu 2007) and can also significantly affect soil properties (Wang et al. 2006) and as such, might contribute to desertification on the plateau.

\subsection{Grassland degradation}

Grassland occupies an area of about 1.5 million $\mathrm{km}^{2}$, and constitutes two thirds of the total plateau area. The main types of vegetation distributed in the Tibetan Plateau are alpine cold meadow, steppe meadow, and alpine cold steppe (Wang et al. 2006). Alpine meadow is a unique natural landscape and an important grassland resource, which cannot be found in such abundance anywhere else on Earth. It covers an area of about $7 \times 10^{5} \mathrm{~km}^{2}$, accounting for nearly $50 \%$ of the total usable grassland on the plateau (Wang and $\mathrm{Fu}$ 2004). Evidence of grassland degradation is very widespread on the Tibetan Plateau. There is currently about half million $\mathrm{km}^{2}$ of degraded grassland, among which severely degraded grassland accounts for approximately $16 \%$ and often called as 'Black Soil Type' by local people (Wang et al. 2006). Most of the severely degraded grassland is created in the headwater areas of the Yangtze and Yellow Rivers of the TP and it is subordinate to bare land (Shang and Long 2007). The reasons for the degraded grassland include warmer temperature, variations of precipitation, decreasing glaciers, melting frozen soil, overgrazing and rat damages (e.g., Shang and Long 2007). Grassland degradation leads to changes of plant species composition, especially changes in grass and sedge species, dramatic drops in plant production, loss of species diversity, and dense sod layer of the natural steppe meadow (Wang et al. 2006).

It is difficult to restore the alpine degraded ecosystem due to the unique "inertia" of Tibetan Plateau grassland and an integrated analysis from all the grassland agricultural interfaces and "soil-grass-livestock-socio-economic-demographic" composite system can make the whole system develop in an un-healthy way (Shang and Long 2007). Recently, several experiments and studies have been performed, for example, the impacts of mounds created by the plateau pika, the dominant animal species in the alpine meadows and steppes of the TP, on the soil erosion and vegetation succession in Nagqu County, TAR (Wei et al. 2007).

\subsection{Deforestation and afforestation}

Deforestation occurs when forest is converted to another land cover type or when the forest fraction falls below a minimum percentage threshold $-10 \%$ according to the United Nations (U.N.) Food and Agriculture Organization (FAO 2001). Deforestation on the TP begins in the 1950s and accelerated in the 1960s (Studley 1999; Houghton and Hackler 2003), due to unsustainable logging practices (Studley 1999; Houghton and Hackler 2003), agricultural use and urbanization (Liu et al. 2005a). The forest on the TP fulfils a crucial hydrological function both in and beyond China. The trees were found at an elevation of up to 4,860 m (Miehe et al. 2008). As shown in Fig. 2a, the steep slopes of the southeast TP were mostly covered by coniferous forest in 1950, which represented China's largest forest resource (Studley 1999). As shown in Fig. 2b, the forest of the southeastern TP has merely disappeared and been replaced mainly by cropland and built-up areas (Houghton and Hackler 
2003). In the TAR, the forest cover reduced from 9\% (1950) to 5\% (1985), in Yunnan from 55\% (1950's) to 30\% (1975), and in Sichuan from 30\% (1950) to 6.5\% (1998, Studley 1999).

Deforestation on the TP may impair forest functions of safeguarding watersheds and river flow (Houghton and Hackler 2003). For example, deforestation in the upper reaches of the Yangtze basin in China led to a reduction of forest cover from $22 \%$ of total area in 1957 to only $10 \%$ in 1986. As a result, soil erosion from the upper reaches and siltation in the middle and lower reaches has intensified. Sharma et al. (2000) used a water balance and distributed deterministic modelling approach and found that runoff would decrease in the scenario of a maximum increase in forest areas below 4,000 $\mathrm{m}$, while it would increase in the case of a possible maximum conversion of forest into agricultural land under contemporary climate conditions in the Kosi Basin, located in the mountainous area of the central Himalayas. A General Circulation Model (GCM) simulation also suggests that deforestation would decrease transpiration and increase precipitation locally, especially in spring, exerting a warmer and wetter summer climate, but colder in autumn and winter on the TP (Cui et al. 2007a). These changes might suggest important hydrological implications for the rivers originating from the TP (as shown in Fig. 3). It could possibly worsen the flooding/drought disasters in these rivers and affect the regional Asian climate. Phenomena such as the significant drying along the middle and lower reaches of Yellow River might worsen the recent drought problems in this area; the significant wetting at the upper Yangtze River might increase the risk of flooding disasters in this area and downstream.

Afforestation is considered as one of the most effective practices to improve environmental quality in north-western China. In 1998, the Chinese central government recognized the disastrous consequences of forest degradation resulting in the loss of biodiversity, unacceptable levels of soil erosion and catastrophic flooding. A new forest policy called the Natural Forest Conservation Program (NFCP) was implemented in 1998 (Zhang et al. 2000). Reforestation of the eroded semi-desert landscape of the southeast TP might be extremely difficult, but still appears to have a huge potential (Miehe et al. 2003). Figure 2b also shows the new forest cover including natural forest as well as plantations over the central TP region in the

Fig. 3 Changes of annually averaged daily surface runoff [unit: $\mathrm{mm} / \mathrm{day}$ ] due to deforestation on the TP with blue colour for increase while red for decrease. Statistical significance of $90 \%$ and $95 \%$ is shaded. Black thick contour shows the location of the Tibetan Plateau. Blue thick lines show the locations of Yellow River (upper) and Yangtze River. Conveyed from Fig. 8 in

Cui et al. (2007a)

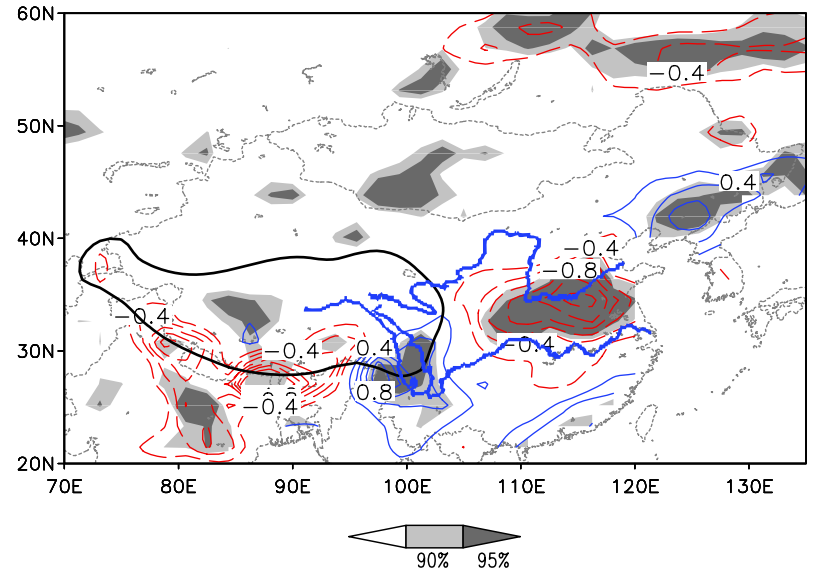


year 2000. In Datong County, Qinghai Province, about $20 \mathrm{~km}^{2}$ of man-made plant community is preserved after the launch of the Returning Farmland to Forest project in the 1980s (Yin et al. 2004). Experimental reforestation trials on the southern slopes above Lhasa, the capital of TAR, shows that treeless areas between the current relicts were forested in the past and could become forested again if human interference were excluded (Miehe et al. 2008). As the lack of fire wood is a severe limitation of rural economy in Southern TAR, it is necessary to introduce forest rehabilitation measures with indigenous forest species that do not depend on the decreasing supply of irrigation water (Miehe et al. 2003).

\subsection{Desertification}

Sandy desertification land of the TP covers a total area of about $3 \times 10^{5} \mathrm{~km}^{2}$ accounting for $14 \%$ of the plateau's total area, of which moderate sandy desertification land occupies $55.4 \%$, slight and serious sandy desertification land constitute $30.8 \%$ and $13.7 \%$ respectively (Liu et al. 2005b). The sandy desertified lands mainly occur in river valleys, lake basins and piedmont dilluvial and alluvial plains, especially seriously sandy desertified lands are mainly distributed in the valleys of the Yarlung-Zangbo, Pengqu, Yangtze and Yellow rivers and their tributary valleys, and at the shores of Qinghai Lake, Nam Co Lake and Bange Lake, etc. (Liu et al. 2005b). Desertification is having extremely negative effects on farmlands, grasslands, highways, and water conservation projects (Liu et al. 2005b). The desertificationinduced sand deposition in the river source area, which might raise the riverbed, is a factor that can be made responsible for flooding disasters downstream, for example the catastrophic one in 1998 (Wang et al. 2000). The upper reaches of the Yellow River consist of extensive grasslands of intrinsic ecological value that have long suffered from grassland degradation and desertification resulting from overgrazing (Zeng et al. 2003). Desertification is caused by both natural and human factors (Zou et al. 2002). The natural factors include the TP's harsh and fragile environment, while the man-made factors are related to over-population and excessive exploitation of natural resources.

\subsection{Socio-economic development}

The distribution of vegetation on the TP is determined by environmental conditions as well as by human disturbance, which is usually extremely spatially heterogeneous (Ni 2000). Land use represents the most substantial human alteration of the Earth system for a long period (Vitousek et al. 1997). The great expansion in human activity on the TP is causing significant changes of natural conditions. For example, the desertified land in TAR is always found in the densely populated regions, where human activities are intensive (Zou et al. 2002). With simulations of an Atmospheric GCM, Cui et al. (2006) found that anthropogenic land cover change on the TP might exert a warmer and drier climate on the TP, similar to the trends found in northern TP (Niu et al. 2004), and modifies the Asian monsoon intensity as well. Several major aspects of urbanization on the TP will be discussed in the rest of this section. 


\subsubsection{Population}

There are no accurate estimates of population change on the TP as population statistics in China are normally based on governmental other than geographical areas. Population in TAR has increased rapidly from 1960 (1.2 million) to 1990 (2.2 million), contributing to both urbanization and changing landscape (Zou et al. 2002). For instance, Lhasa, the capital of the TAR, has grown by $2400 \%$ in the last 50 years (Du et al. 2004). The human population in the western Himalayan states has increased around three times during the second half of the 20th century (Yadav et al. 2004). As a result of growing population, agriculture has been expanded. In the Garhwal region at the Himalaya Mountains, $50 \%$ of the area expansion of agricultural land during 1963-1993 was done in formerly forest areas (Sen et al. 2002).

\subsubsection{Transportation construction}

The Qinghai-Tibet Highway and Railway run cross the TP from north (Xining, Qinghai Province) to south (Lhasa, TAR) with total lengths of 2,055 km and 1,956 km respectively. The railway includes two segments: one is from Xining to Golmud which has been running for over 20 years; the other is from Golmud to Lhasa which was open to traffic in July of 2006. The Highway had been changed a few times since it was constructed in the 1950s. The running of Qinghai-Tibet Highway and Railway drives the growth of local economy, which attracted mass people to gather along the traffic lines. All these strengthened the intensity of land use along the lines, which include grassland, shrub, meadow, desert, and forest (Ding et al. 2006). The highway and railway traverse $560 \mathrm{~km}$ of permafrost-impacted ground, which has been degrading and retreating during the last quarter century (Jin et al. 2006). Based on the data from the Advanced Very High Resolution Radiometer (AVHRR) NDVI from 1981 to 2001, the spatial distribution and dynamic change of land cover along the QinghaiTibet Highway and Railway, extending to $100 \mathrm{~km}$ at both sides, reveal that local human activity is the key factor affecting land cover followed by the climate changes that is due to global anthropogenic effects (Ding et al. 2006).

\subsubsection{Tourism}

The TP, especially TAR, is a very popular tourism destination due to its impressive natural scenery and cultural distinction. In 2001, TAR hosted 686,100 domestic and foreign tourists, earning 750 million RMB and 43.68 million US dollars. In 2005 TAR received around 1.8 million tourists who generated revenues of nearly 2 billion RMB (about US $\$ 250$ million). The annual number of tourists to TAR is expected to exceed 5 million by 2010 predicted by Tibetan Tourism Department (Xinhua News: http://www.china.org.cn/english/2006/Jul/173726.htm). Tourism is a major source of income in TAR and influences heavily the local economy. However, it could also heavily impact on environment, if not properly managed. Alone the needs for transport, food and accommodation will exert enormous stress to the ecology of the TP. 


\section{Future scenarios of land cover on the Tibetan Plateau}

The response of life zones on the TP to climate changes as predicted by Zhang et al. (1996b) showed that the natural vegetation would shift northwards and westwards from the present position due to climate warming and that most of the dominant tree species would shift northwards and westwards as the climate gets warmer for a scenario of $\mathrm{CO}_{2}$ concentration of $500 \mathrm{ppmv}$ (Song et al. 2004). Natural vegetation such as tropical and sub-tropical forests, coniferous forests, and alpine meadows would increase, but decrease of alpine steppe, alpine desert, and polar desert is expected (Ni 2000). Model simulations suggest that the perennial permafrost areas of the TP would mostly disappear, while the no-permafrost area would greatly increase under future global warming climate and this would accelerate the desertification of the TP (Ni 2000).

However, all these projections of land use changes are based on future possible surface temperature and/or precipitation produced by GCM scenario simulations. As always, it is difficult to determine whether or not the models are "good enough" to be trusted when used to make predictions for the future (Covey et al. 2003). In addition, high uncertainty exists when climate is simulated over the TP by GCMs (Cui et al. 2006, 2007a) or Regional Climate models (RCM; Cui et al. 2007b; Christensen et al. 2007).

\section{Conclusions and outlooks}

This paper reviewed the published literature concerning the climate and land cover changes on the Tibetan Plateau during the last 50 years. Although observational data available for the plateau are limited, it showed that the plateau got generally warmer and wetter in some regions in the last half century. Responding to climate change and anthropogenic pressure, the vegetation and environment went through changes as well. Human factors are even more important given the immense population increase, social-economic and transport development. The major land cover changes include permafrost and grassland degradation, deforestation and desertification.

The quantitative evaluation of climate and land cover changes on the TP and their possible interactions is very difficult because reliable long term meteorological and land surface observational data are not available. A further complication is that the land-atmosphere interactions are highly nonlinear and the GCMs with current resolution only poorly perform on the TP. The few model studies published so far found also important hydrological implications of land cover changes on the TP on local climate and Asian area, where one third of world population lives. Further integrated investigations on the ecosystem on the TP are highly recommended to international scientific community. Given the outreach of changes in land use of the Tibetan Plateau, such scientific projects need to be truly integrative and international.

Open Access This article is distributed under the terms of the Creative Commons Attribution Noncommercial License which permits any noncommercial use, distribution, and reproduction in any medium, provided the original author(s) and source are credited. 


\section{References}

Bengtsson L, Hagemann S, Hodges KI (2004) Can climate trends be computed from reanalysis data? J Geophys Res 109:D11111. doi:10.1029/2004JD004536

Beniston M (2003) Climatic change in mountain regions: a review of possible impacts. Clim Change 59:5-31

Beniston M, Fox DG et al (1996) The impacts of climate change on mountain regions. In: Second assessment report of Intergovernmental Panel on Climate Change (IPCC), Chapter 5. Cambridge University Press, Cambridge

Braeuning A, Mantwill B (2004) Summer temperature and summer monsoon history on the Tibetan Plateau during the last 400 years recorded by tree rings. Geophys Res Lett 31:L24205. doi:10.1029/2004GL020793

Brovkin V, Sitch S, von Bloh W, Claussen M, Bauer E, Cramer W (2004) Role of land cover changes for atmospheric $\mathrm{CO}_{2}$ increases and climate change during the last 150 years. Glob Chang Biol 10:1-14

Charney JG (1975) Dynamics of deserts and droughts in the Sahel. Q J R Meteorol Soc 101: 193-202

Cheng G, Wu T (2007) Responses of permafrost to climate change and their environmental significance, Qinghai-Tibet Plateau. J Geophys Res 112:F02S03. doi:10.1029/2006JF000631

Christensen JH et al (eds) (2007) Regional Climate Projections. In: Solomon S et al (eds) Climate change 2007: the physical science basis. Contribution of working group I to the fourth assessment report of the intergovernmental panel on climate change. Cambridge University Press, Cambridge, United Kingdom and New York, NY, USA

Covey C, AchutaRao KM, Cubasch U, Jones P, Lambert SJ, Mann ME, Philips TJ, Taylor KE (2003) An overview of results from the Coupled Model Intercomparison Project (CMIP). Glob Planet Change 37:103-133

Cui XF, Graf HF, Langmann B, Chen W, Huang RH (2006) Climate impacts of anthropogenic land use changes on the Tibetan Plateau. Glob Planet Change 54:33-56

Cui XF, Graf HF, Langmann B, Chen W, Huang RH (2007a) Hydrological impacts of deforestation on the southeastern Tibetan Plateau: a model study. Earth Interact 11(15):1-18

Cui XF, Langmann B, Garf HF (2007b) Summer monsoonal rainfall simulation on the Tibetan Plateau with a regional climate model using a one-way double-nesting system. Sci Online Lett Atmos 3:49-52

Ding M, Zhang Y, Shen Z, Liu L, Zhang W, Wang Z, Bai W, Zheng D (2006) Land cover change along the Qinghai-Tibet Highway and Railway from 1981 to 2001. J Geogr Sci 16(4):387-395

Ding M, Zhang Y, Liu L, Zhang W, Wang Z, Bai W (2007) The relationship between NDVI and precipitation on the Tibetan Plateau. J Geogr Sci 17(3):259-268

Du M, Kawashima S, Yonemura S, Zhang X, Chen S (2004) Mutual influence between human activities and climate change in the Tibetan Plateau during recent years. Glob Planet Change 41:241-249

FAO (2001) State of the world's forestry 2001. http://www.fao.org

Frauenfeld OW, Zhang T, Serreze MC (2005) Climate change and variability using European centre for medium-range weather forecasts reanalysis (ERA40) temperatures on the Tibetan Plateau. J Geophys Res 110:D02101. doi:10.1029/2004JD005230

GLC2000 (2003) Global landcover classification for the year 2000. http://www-gem.jrc.it/glc2000/

Houghton RA, Hackler JL (2003) Sources and sinks of carbon from land-use change in China. Glob Biogeochem Cycles 17(2):1034. doi:10.1029/2002GB001970

Hsu HH, Liu X (2003) Relationship between the Tibetan Plateau heating and East Asian summer monsoon rainfall. Geophys Res Lett 30:D2066. doi:10.1029/2003GL017909

Jin H, Zhao L, Wang S, Jin R (2006) Thermal regimes and degradation modes of permafrost along the Qinghai-Tibet Highway. Sci China Ser D Earth Sci 49:1170-1183

Kalnay E, Cai M (2003) Impact of urbanization and land-use change on climate. Nature 423(6939):528-531

Klein Goldewijk K (2001) Estimating global land use change over the past 300 years: the HYDE database. Glob Biogeochem Cycles 15(2):417-433

Kondo J, Xu J (1997) Seasonal variations in the heat and water balances for nonvegetated surfaces. J Appl Meteor 36:1676-1695

Lin Z, Zhao X (1996) Spatial characteristics of changes in temperature and precipitation of the Qinghai-Xizang (Tibet) Plateau. Sci China Ser D 39:442-448 
Liu XD, Chen B (2000) Climate warming in the Tibetan Plateau during recent decades. Int J Climatol 20:1729-1742

Liu XD, Yin ZY (2002) Sensitivity of East Asian monsoon climate to the Tibetan Plateau uplift. Palaeogeogr Palaeoecol 183:223-245

Liu J, Tian H, Liu M, Zhuang D, Melillo JM, Zhang Z (2005a) China's changing landscape during the 1990s: large-scale land transformation estimated with satellite data. Geophys Res Lett 32:L02405. doi:10.1029/2004GL021649

Liu YH, Dong GR, Li S, Dong YX (2005b) Status, causes and combating suggestions of sandy desertification in Qinghai-Tibet Plateau. Chin Geogr Sci 15:289-296

Ma Y, Su Z, Koike T, Yao T, Ishikawa H, Ueno K, Menenti M (2003) On measuring and remote sensing surface energy partitioning over the Tibetan Plateau-from GAME/Tibet to CAMP/ Tibet. Phys Chem Earth 28:63-74

Ma Y, Zhong L, Su Z, Ishikawa H, Menenti M, Koike T (2006) Determination of regional and seasonal variations of land surface heat fluxes from Landsat-7 enhanced thematic mapper data over the central Tibetan Plateau area. J Geophys Res 111:D10305. doi:10.1029/2005JD006742

Manabe S, Broccoli AJ (1990) Mountains and arid climate of middle latitudes. Science 247:192-195

Manabe S, Terpsta TB (1974) The effects of mountains on the general circulation of the atmosphere as identified by numerical experiments. J Meteorol Soc Jpn 31:3-42

Miehe G, Miehe S, Koch K, Will M (2003) Sacred forests in Tibet. Mt Res Dev 23(4):324-328

Miehe G, Miehe S, Will M, Opgenoorth L, Duo L, Dorgeh T, Liu J (2008) An inventory of forest relicts in the pastures of Southern Tibet (Xizang A.R., China). Plant Ecol 194:157-177

Ni J (2000) A simulation of biomes on the Tibetan Plateau and their responses to global climate change. Mt Res Dev 20(1):80-89

Niu T, Chen L, Zhou Z (2004) The characteristics of climate change over the Tibetan Plateau in the last 40 years and the detection of the climate jumps. Adv Atmos Sci 21(2):193-203

Qin B, Huang Q (1998) Evaluation of the climatic change impacts on the inland lake-a case study of Lake Qinghai, China. Clim Change 39(4):695-714

Sato T, Kimura F (2007) How does the Tibetan Plateau affect the transition of Indian monsoon rainfall? Mon Weather Rev 135:2006-2015

Sen KK, Senwal RL, Rana U, Nautiyal S, Maikuri RK, Rao KS, Saxena G (2002) Patterns and implications of land use/cover change: a case study in Pranmati watershed (Garhawal Himalaya, India). Mt Res Dev 22:56-62

Shang Z, Long R (2007) Formation causes and recovery of the "Black Soil Type" degraded alpine grassland in Qinghai-Tibetan Plateau. Front Agric China 1:197-202

Sharma KP, Vorosmarty CJ, Moore B III (2000) Sensitivity of the Himalayan hydrology to land-use and climate changes. Clim Change 47:117-139

Shimizu S, Ueno K, Fujii H, Shirooka R, Liu L (2001) Mesoscale characteristics and structures of stratiform precipitation on the Tibetan Plateau. J Meteorol Soc Jpn 79(1B):435-461

Simmons AJ, Gibson JK (2000) The ERA40 project plan. ERA40 project report series, no 1. ECMWF, Reading, UK

Singh J, Yadav RR (2005) Spring precipitation variations over the western Himalaya, India, since A.D. 1731 as deduced from tree rings. J Geophys Res 110:D01110. doi:10.1029/2004JD004855

Song MH, Zhou CP, Hua QY (2004) Distributions of dominant tree species on the Tibetan Plateau under current and future climate scenarios. Mt Res Dev 24(2):166-173

Stich S, Brovkin V, von Bloh W, van Vuuren D, Eickhout B, Ganopolski A (2005) Impacts of future land cover changes on atmospheric $\mathrm{CO}_{2}$ and climate. Glob Biogeochem Cycles 19:GB2013. doi:10.1029/2004GB002311

Studley J (1999) Forests and environmental degradation in SW China. Int For Rev 1(4):260-265

Suh MS, Lee DK (2004) Impacts of land use/cover changes on surface climate over east Asia for extreme climate cases using RegCM2. J Geophys Res 109:D02108. doi:10.1029/2003JD003681

Tanaka K, Tamagawa I, Ishikawa H, Ma Y, Hu Z (2003) Surface energy budget and closure of the eastern Tibetan Plateau during the GAME-Tibet IOP 1998. J Hydro 283:169-183

Tang MC, Cheng GD, Lin ZY (eds) (1998) Contemporary climatic variations over the QinghaiXizang (Tibet) Plateau and their influences on environments. Guangdong Science and Technology Press, Guangzhou (in Chinese)

Tong C, Wu Q (1996) The effect of climate warming on the Qinghai-Tibet highway. Cold Reg Sci Technol 24:101-106

Ueno K, Fujii H, Yamada H, Liu L (2001) Weak and frequent monsoon precipitation over the Tibetan Plateau. J Meteorol Soc Jpn 79(1B):419-434 
Vitousek PM, Mooney HA, Lubchenco L, Melillo JM (1997) Human domination of Earth's ecosystems. Science 277:494-499

Wang SL, Jin HJ, Li SX, Zhao L (2000) Permafrost degradation on the Qinghai-Tibet Plateau and its environmental impacts. Permafrost Peroglac Process 11:43-53

Wang X, Fu X (2004) Sustainable management of alpine meadows on the Tibetan plateau: problems overlooked and suggestions for change. Ambio 33(3):169-171

Wang W, Wang Q, Wang H (2006) The effect of land management on plant community composition, species diversity, and productivity of alpine Kobersia steppe meadow. Ecol Res 21:181-187

Wei X, Li S, Yang P, Cheng H (2007) Soil erosion and vegetation succession in Alpine Kobresia Steppe Meadow caused by Plateau Pika—a case study of Nagqu County, Tibet. Chin Geogr Sci 17:75-81

Xu J, Haginoya S (2001) An estimation of heat and water balances in the Tibetan Plateau. J Meteorol Soc Jpn 79(1B):485-504

Xu X, Chen H, Levy JK (2008) Spatiotemporal vegetation cover variations in the Qinghai-Tibet Plateau under global climate change. Chin Sci Bull 53:915-922

Yadav RR, Park WK, Singh J, Dubey B (2004) Do the western Himalayas defy global warming? Geophys Res Lett 31:L17201. doi:10.1029/2004GL020201

Yang M, Wang S, Yao T, Gou X, Lu A, Guo X (2004) Desertification and its relationship with permafrost degradation in Qinghai-Xizang (Tibet) plateau. Cold Reg Sci Technol 39: $47-53$

Ye D, Gao Y (eds) (1979) The meteorology of the Qinghai-Xizang (Tibet) Plateau. Sciences Press, Beijing (in Chinese)

Ye D, Wu GX (1998) The role of the heat source of the Tibetan Plateau in the general circulation. Meteorol Atmos Phys 67:181-198

Yin ZY, Lin ZY, Zhao XY (2000) Temperature anomalies in central and eastern Tibetan Plateau in relation to general circulation patterns during 1951-1993. Int J Climatol 20:1431-1449

Yin J, Liu C, Zhao W, He K (2004) Tree productivity and water potential productivity in returning farmland to forest project in Datong County, Qinghai Province. Forest Stud China 6:36-42

You Q, Kang S, Aguilar E, Yan Y (2008) Changes in daily climate extremes in the eastern and central Tibetan Plateau during 1961-2005. J Geophys Res 113:D07101. doi:10.1029/2007JD009389

Zeng Y, Feng Z, Cao G (2003) Land cover change and its environmental impact in the upper reaches of the Yellow River, northeast Qinghai-Tibetan Plateau. Mt Res Dev 23(4):353-361

Zhang H, McGuffie K, Henderson-Sellers A (1996a) Impacts of tropical deforestation. Part II: the role of large-scale dynamics. J Climate 9:2498-2521

Zhang XS, Yang DA, Zhou GS, Liu CY, Zhang J (1996b) Model expectation of impacts of global climate change on biomes of the Tibetan Plateau. In: Omasa K (ed) Climate change and plants in East Asia. Springer, Tokyo, pp 25-38

Zhang P, Shao G, Zhao G, Le Master DC, Parker GR, Dunning JB Jr, Li Q (2000) China's forest policy for the 21st century. Science 288:2135-2136 (in policy forum)

Zou X, Li S, Zhang C, Dong G, Dong Y, Yan P (2002) Desertification and control plan in the Tibet Autonomous Region of China. J Arid Environ 51:183-198 